\title{
食物・栄養素捸取量の分布型について
}

\author{
光崎研一 * 福岡秀雄 ${ }^{*} \cdot$ 押田敏雄* ${ }^{*}$ 赤堀文昭* \\ 光崎龍子* $\cdot$ 和気三男**
}

\section{Distribution of the Amount of Food and Nutritive Substance Intake}

\author{
Kenichi KOHZAKI ${ }^{1}$, Hideo FUKUOKA ${ }^{1)}$, Toshio OSHIDA ${ }^{1)}$, Humiaki AKABORI ${ }^{11}$, \\ Ryuko KOHZAKI ${ }^{1)}$ and Mitsuo WAKI ${ }^{2)}$
}

1) Azabu University, 1-17-71, Fuchinobe, Sagamihara-shi, Kanagawa 229

2) Kanagawa Presection Juniory College of Nutrition 399, Sakuragaoka, Hodogaya-ku, Yokohama-shi 240

\section{Summary}

Based on the data of the investigation of nutritions with certain female dietetics junior college students and their families as subjects, the authors examined the types of frequency distribution of the volume of intake classified by food groups and by nutritional elements. The results were as follows:

1. For the distribution types of the volume of intake classified by food groups, the groups found in the neighbourhood of the Pólya's distribution were cereals, potatoes, sugars, sweets, fruits, fish and shellfish, eggs, milk and dairy products, vegetables, mushrooms, seaweeds, and fancy drinks, while those found in the neighbourhood of the binomial distribution were oils and fats, and meats. Further, those found in the neighbourhood of Poisson's distribution were beans, coloured vegetables, and fruits. However, the normal distribution was not observable.

2. The food groups showing a similar distribution to that observed in a national survey (1970: Toyokawa) were potatoes, beans, milk and dairy products, coloured vegetables, fruits, sweets, and seaweeds. Among these foods, potatoes fitted to Pólya's distribution, and agreed with the outcome of the national survey.

3. Classified by the sex, the food groups found in the neighbourhood of Poisson's distribution both in men and wommen were sugars, fruits, meats, milk and dairy products, mushrooms, seaweeds, and fancy drinks. Oils and fats, beans, and coloured vegetables were found in the neighbourhood of Pólya's distribution for men, while the outcome for women was found in the neighbourhood of the binomial distribution.

4. The cereals, which are the staple foods, were found in the neighbourhood of Poisson's distribution for men and in the neighbourhood of the binomial distributionin for women, whereas potatoes were found in the neighbourhood of the binomial distribution for men and in the neighbourhood of Poisson's distribution for women.

* 麻布大学

干229 相模原市㴊野辺 1-17-71

** 神奈川県立栄養短大

テ240 横浜市保土ヶ谷区桜が丘 339 
5. In the distribution types of nutritional elements classified by the sex, energy, calsium, phosphor, and vitamin $B_{1}$ and $B_{2}$ were found in the neighbourhood of Polya's distribution, and ashes were found in the neighbourhood of Poisson's distribution, both for men and women.

6. As classified by the age, the neighbourhood of Poisson's distribution was shown more for the younger generation. For fish and shellfish, they were found in the neighbourhood of Polya's distribution for adults while for youths they were found in the neighbourhood of Poisson's distribution.For meats, howerer, the outcome was reverse.

7. It was noted that the significance of the mean as the representative value was restricted when observing the collective values, and therfore the authors' experiment to find out the distribution types from the frequency distribution classified by the volume of intake of food groups and nutritional elements, which led to the clarification of eating styles, appeared to be very significant.

わが国では，栄養改善法に基づき毎年栄盖調查が 国民的規模で行なれれて护り3，かつ，その状況は 「国民衛生の動向」に明らかにされている。栄養改善 の過程をみると，栄養素搷取量の改善は戦後めざま しいものの，まだいくつかの閴を残している。た 上之ばわが国の死因順位の変化などは，栄養改善に かかわる問題が背景にあり，これらの複雑な因果関 係によ一て起っているものと推察される。

豊川らは年7-111.13-15), この国民栄養調查資料をもと に，その実態を種々な角度で解析しているが，なか でも食物攝取状況の度数分布が食品群別に相違し NORMAL 分布ではなく POLYA-EGGENBERG（以下 POLYA と略す) 分布あるいは PoISSON 分布型にそれ ぞれ適合していることを指摘している。食物捸取状 況に NORMAL 分布以外の分布型が出現することは, 食品の違いによりその損取量・方法 ${ }^{16}$ ) (年齢・性・暂 好・地域などの要因を含む）に差異のあることを示 しており ${ }^{1.4)}$ ，このことが栄養素摂取量にどのような 影響を与え, 基準とされている栄養要求量がどのよ うな形で充足されているのか興味あるところである。 そこで, 食品群別攝取量の度数分布型を調べ栄養捸 取状況の統学的な検討を試みた。

\section{供試データと解析方法}

女子栄養短期大学学生とその家族を対象とし, 国 民栄養調查と同様に連続 3 日間, 実際の食品搨取量 を秤量し個人別カードに記入させた。この资料にも とづき, 食品群別・栄養素摄取量別（四訂, 日本食 品成分表：医歯薬出版をもとにして, 計算を行なっ た）の度数分布を作製し，分布型適合の検討を試み た。また,この調查集団の性別年齡構成は表 1 に示 すとおりである。

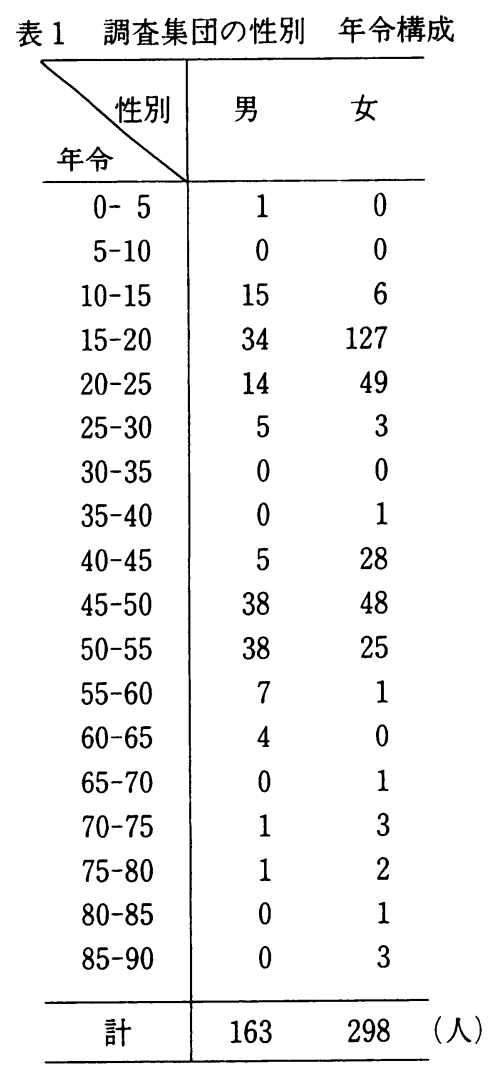

以上の情報処理は，麻布大学情報処理セン夕端末 を通じ, 東京大学大型計算機センタ H I T C 8700/ 8800 を利用し自製のプログラムによって行った。

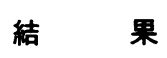
1）食品群別摄取量（1人1日当りの量）の度数分 布

本調查集団の食品群別摄取量の度数分布は, 図 1 -1，1-2および1-3に示すように，1人 1 日当り 

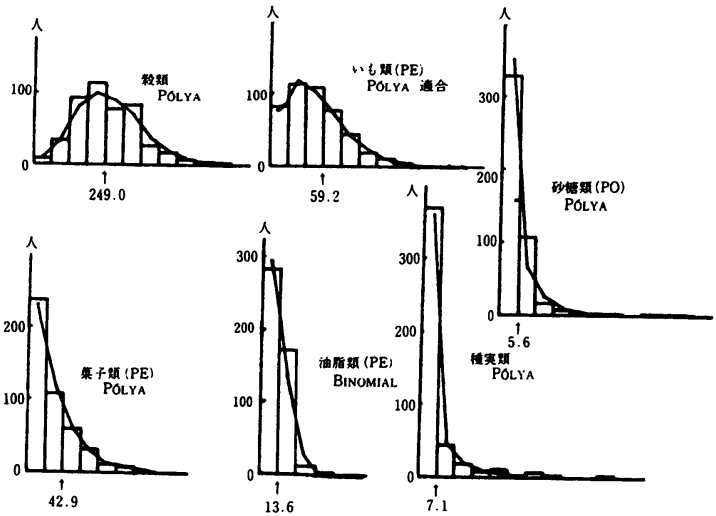

図1-1 食品群捸取量の度数分布
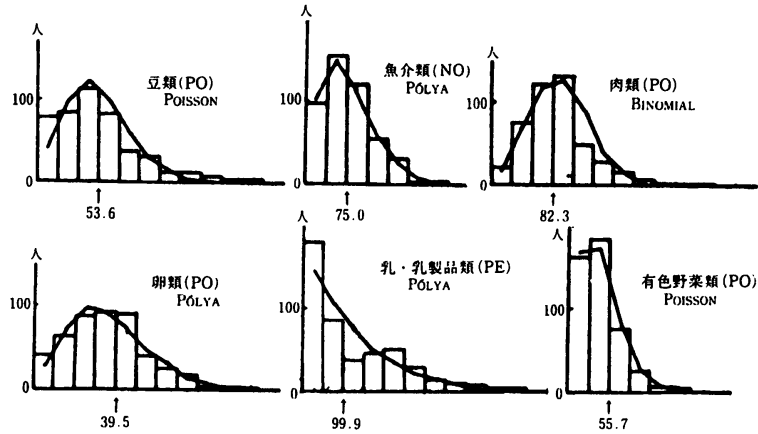

図1-2 食品群摂取量の度数分布

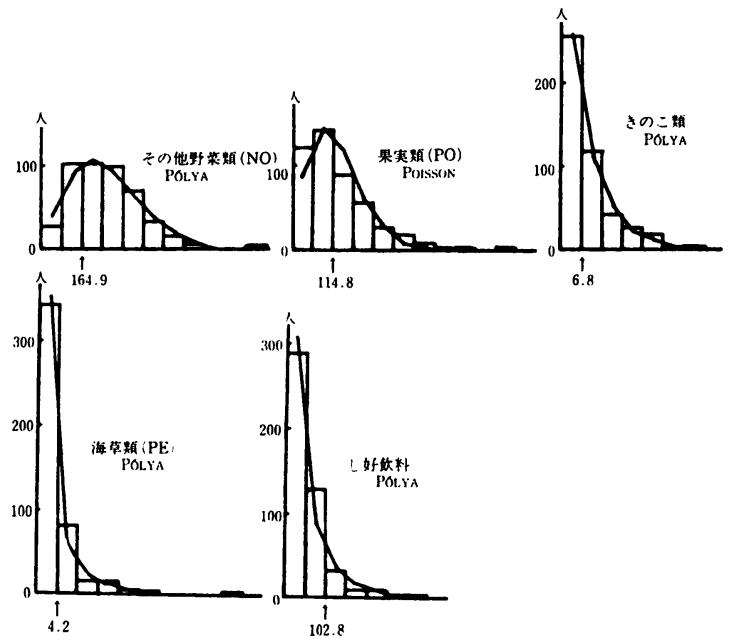

図1-3 食品群攝取量の度数分布

注. 1.†：1人 1 日当り摄取量 $(\mathrm{g})$ の算術平均值

2.（）内は豊川から示した分布型で，NO=NORRAL, $\mathrm{PO}=$ POISSON,$\quad \mathrm{PE}=$ POLYA

の各食品捸取量をもとに作製し，図中の実線は各度 数分布に近似する分布曲線を示す。

摂取量度数分布が POLYA 分布近似を示す食品群 は, 款類, 砂糖類, 菓子類, 種実類, 魚介類, 卵類, 乳・乳製品類, その他の野菜類, きのこ類, 海草類
および嗜好飲料であり，BINOMIAL 分布近似を示す のは, 油脂類および肉類, さらに, PoIsson 分布近似 食品群は, 豆類, 有色野菜類および果実類であった。 これらの中で, いも類だけが POLYA 分布に適合して いた。また，各食品群別に（）内に示した分布型 は，豊川が行なった国民栄養調査による適合分布で あり，われわれの結果が豊川と同様な分布を示す食 品群は, いも類, 菓子類, 豆類, 乳・乳製品類, 有 色野菜類，果実類および海草類であった。

われわれの調查における各食品群の摂取量分布型 の状況と豊川らの示した分布型とを比較一覧したの が表 2 である。

本調査においては, NORMAL 分布型は観察されな かった。BINOMIAL 分布近似を示した油脂類は豊川 ではPOLYA 分布型であった。さらに, POLYA 分布型 近似の砂糖類および卵類は, 豊川では PoISSON 分布 型を示した。

豊川の示した分布型と本調査の分布型が相違する 食品群が多かったことから，それが性および年㱓の 相違によるものと考之性別, 年齢別に食品群および 栄養素の捸取状況の分布型を再検討した。

まず，性別の各食品群別攝取量の度数分布のうち, 菓子類・肉類の場合を㘡 2-1および $2-2$ に示した。 菓子類では, 男性163名の捸取量分布型は BINOMIAL 分布近似で，1 1 1 日当り平均摂取量は, $29.5 \mathrm{~g}$, 女 性298名の攝取量分布は, POLYA 分布近似で 1 人 1 日当り平均摂取量は $49.7 \mathrm{~g}$ であった。

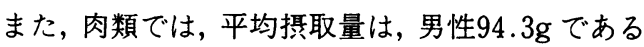
のに対して，女性は $75.5 \mathrm{~g}$ と少なかった。分布型をみ ると男性は POLYA 分布近似を, 女性は BINOMIAL 分 布近似を示した。

性別の栄養素摂取量の度数分布を図 3 に示した。 エネルギー (cal) について 1 人 1 日当り平均捸取量 は男性 $2052 \mathrm{kcal}$, 女性 $1704 \mathrm{kcal}$ でエネルギー平 均攝取量に性差がみられるが, 男女ともその分布型 はPOLYA 分布近似を示し, 分布型に性差はみられな かった。

表 3 には性別の食品群別および栄養素別摄取量分 布を示した。男女とも POISSON 分布近似を示した食 品群は, 砂糖類, 種実類, 肉類, 乳・乳製品類, き のこ類，海草類および嗜好领料であった。主食であ る殻類では, 男は POISSON 分布近似, 女は BINOMIAL 分布近似を示した。エネルギー源であるいも類では， 殼類と比較して分布型が男女いれかわっており，さ らに, 油脂類，豆類および有色野菜類のように男性 
獣医情報科学 No.18，19-26（1987）

表 2 各食品群の損取量分布

\begin{tabular}{|c|c|c|c|c|c|c|}
\hline 食 品 & \multirow{2}{*}{$\begin{array}{c}\bar{x} \\
\text { g/日/人 }\end{array}$} & \multirow{2}{*}{$s$} & \multicolumn{2}{|r|}{ 各種 } & \multicolumn{2}{|l|}{ 分 布 } \\
\hline 群 & & & $\begin{array}{l}\text { NOMAL } \\
\text { (NO) }\end{array}$ & $\begin{array}{c}\text { BINOMIAL } \\
(\text { BIN })\end{array}$ & $\begin{array}{c}\text { PISSON } \\
\text { (PO) }\end{array}$ & $\begin{array}{c}\text { POLYA } \\
\text { (PE) }\end{array}$ \\
\hline 穀類 & 249.0 & 87.4 & & & & \\
\hline いも類 & 59.2 & 41.5 & & & & 00 \\
\hline 砂糖類 & 5.6 & 8.2 & & & 0 & \\
\hline 菓子類 & 42.5 & 48.8 & & & & $\bigcirc$ \\
\hline 油脂類 & 13.6 & 10.8 & & 0 & & O \\
\hline 種実類 & 7.1 & 16.9 & & & & 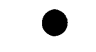 \\
\hline 豆類 & 53.6 & 37.6 & & & $\mathrm{O}$ & \\
\hline 魚介類 & 75.0 & 50.8 & 0 & & & 0 \\
\hline 肉類 & 82.3 & 43.3 & & 0 & O & \\
\hline 卵類 & 39.5 & 22.2 & & & 0 & \\
\hline 乳·乳製品 & 99.9 & 101.8 & & & & $\bigcirc$ \\
\hline 有色野菜類 & 55.7 & 42.0 & & & $\bigcirc$ & \\
\hline その他野菜類 & 164.9 & 79.1 & 0 & & & \\
\hline 果実類 & 114.8 & 96.8 & & & $\bigcirc$ & \\
\hline きのこ類 & 6.8 & 8.3 & & & & \\
\hline 海草類 & 4.2 & 6.6 & & & & $\bigcirc$ \\
\hline 嗜好飲料 & 102.8 & 137.8 & & & & \\
\hline
\end{tabular}

○：皚川ら 1971 ○：調查集団適合分布

：調查集団近似分布

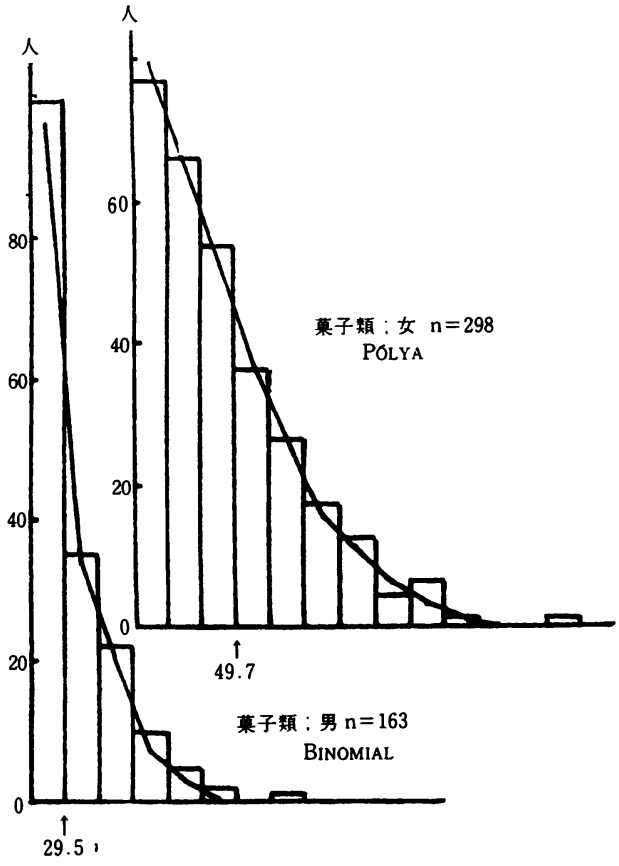

注. $\uparrow: 1$ 人 1 日当り摄取量 $(\mathrm{g})$ の算術平均值 図2-1 食品群捸取量の度数分布

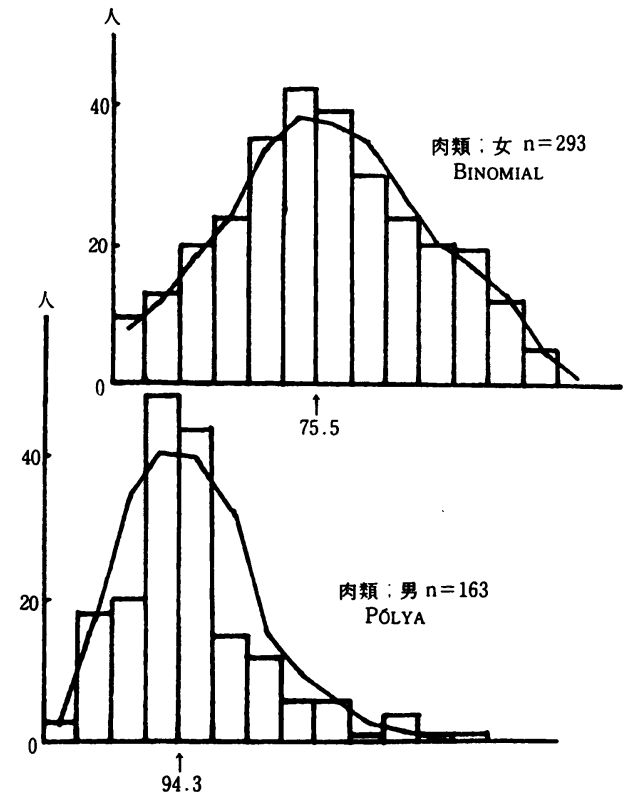

注. †：1人 1 日当り摂取量 $(\mathrm{g})$ の算術平均値 図2-2 食品群摂取量の度数分布 
では POLYA 分布近似を，女性では BINOMIAL 分布近 似を示す食品群がみられ, 各食品群の捸取状況は性 別に異なる傾向がみられた。

栄養素別の分布型をみると, エネルギー, カルシ ウム,リン,ビタミン $\mathrm{B}_{1}$ および $\mathrm{B}_{2}$ では男女とも POLYA 分布近似, 灰分では男女とも POISSON 分布近 似であった。一方，たん白質，糖類および鉄のよう に性別に分布型を異にするものもみられた。

表 4 には年龄構成層別の分布型を示した。青年層 では, PoISSON 分布近似を示す食品群が多かったの に対して，成人層では BINOMIAL 分布近似を示すも のが多かった。魚介類では成人が POLYA 分布近似, 青年が PoISSON 分布に対して, 肉類ではこの逆を示 L, 成人 POISSON 分布近似, 青年 POLYA 分布近似で あった。

また，栄養素別に関しては青年，成人ともに，工 ネルギー，たん白質および脂肪では POLYA 分布近 似, リンは BINOMINAL, ビタミン $\mathrm{B}_{2}$ およびCでは PISSON 分布近似を示した。カルシウムおよび鉄では 年秢構成層別で分布型を異にした。

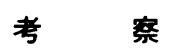

わが国では, 昭和27年, 栄養改善法が制定され,

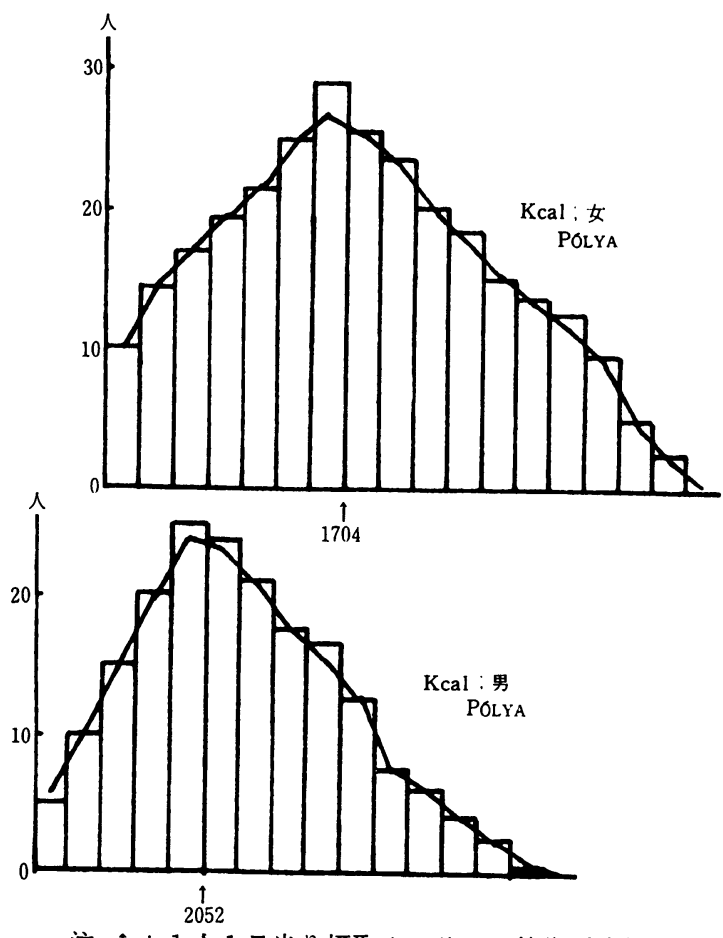

注. ：1人1日当り摂取カロリーの算術平均値

目 3 栄養素摂取量の度数分布
国民栄養調査も法律に基づく調査として実施される ことになった。この目的は，国民の栄養を改善する ことにあるが，わが国の経済成長のめざましさとと もに国民の栄養状態は，栄養改善の目標を超え，泡 食過栄養の状態に至っている。

豊川らは，この国民栄養調查デー夕をもとに，そ の実態を種々な角度から解析している6,8,9 11)。食生 活に関するこのような分野の研究は，栄養素搨取量 が充足されているか否かにとどまりク，集団值につ いての議論が少ないことにかんがみ, 本調查では, 栄養学を尃門分野とする大学に在学している学生と その家族という特種な集団がおりなす食生活の実態 を、捸取量の度数分布型に注目しながら全国の食物 搨取状況と対比させ検討を加えてみた。

豊川の全国レベルの資料では ${ }^{8,111}$, 全食品群に共通 して捸取量の分布型は一峰性であり, BINOMIAL 分 布の範ちゅうにおさまっているが, それでも各食品 群の間には著しい相違がみられる。米はほぼ正規分 布に近似し, その他の野菜類, 魚介類がこれに準じ ているが, 逆に海草類, 乳・乳製品類, 菓子類, い も類および油脂類は摂取量 0 を含む最少区間に最頻 值を持つ POLYA 分布を示し, 卵類, 豆類, 果実類, 有色野菜類, 砂糖類および肉類は BINOMIAL 分布の 極限としての POISSON 分布を示している。

本調查の資料では, POLYA 分布又は近似を示す食 品群として, 殼類, いも類, 砂糖類, 菓子類, 種実 類, 魚介類, 卵類, 乳 - 乳製品類, その他の野菜類, きのこ類, 海草類および嗜好飲料であり, BINOMIAL 分布近似を示すのは, 油脂類および肉類のみであっ た。また, PISSON 分布近似を示すのは, 豆類, 有色 野菜類および果実類であった。このように, 食品群 別捸取量の分布型に相違がみられるのは, 摄取状況 に片寄りがあることを示しており，この点が食生活 形態の実状を把握するための重要ポイントであると 考之る。分布型のもつ意味からみると, BINOMIAL お よび POISSON 分布を示す食品群は, 比較的問題なく 捸取されていると考之られる。現在の食生活の批判 の中で, 殼類, 魚介類および乳・乳製品類の捸取量 の減少が強調されているが, 本調査でも POLYA 分布 を示す食品群がみられたことから考えて, 栄養学に 関連のある学生とその家族にあっても，その食生活 は, 一般に指摘されている傾向と変らないとみるこ とができた。

さらに, 全国レベルに比して本調查における分布 型が, 食品群により異なるものが多かったことか 
表 3 性別, 食品群・栄養素別の摃取量分布

\begin{tabular}{|c|c|c|c|c|c|}
\hline 食品群 性別 & 男 & 女 & 栄養素 性別 & 男 & 女 \\
\hline 穀類 & (O) & 0 & エネルギー & 0 & 0 \\
\hline いも類 & 0 & () & 水分 & (a) & - \\
\hline 砂糖類 & (0) & (0) & たん白質 & 0 & () \\
\hline 菓子類 & 0 & 0 & 脂肪 & (2) & - \\
\hline 油脂類 & 0 & 0 & 糖質 & 0 & 0 \\
\hline 種実類 & (0) & (0) & 繊維 & - & 0 \\
\hline 豆類 & 0 & 0 & 灰分 & (2) & (2) \\
\hline 魚介類 & 0 & 0 & カルシウム & 0 & 0 \\
\hline 肉類 & (0) & (a) & ナトリウム & (2) & - \\
\hline 卵類 & 0 & (a) & リン & 0 & 0 \\
\hline 乳·乳數品類 & (1) & (0) & 鉄 & (2) & 0 \\
\hline 有色野菜類 & 0 & 0 & ビタミン A & - & (2) \\
\hline その他野菜類 & 0 & 0 & ビタミン $\mathrm{B}_{1}$ & 0 & 0 \\
\hline 果実類 & (1) & 0 & ビタミン $\mathrm{B}_{2}$ & 0 & 0 \\
\hline きのこ類 & () & (0) & ニコチン酸 & (2) & - \\
\hline 海草類 & (1) & (2) & ビタミンC & - & 0 \\
\hline 嗜好飲料 & (0) & (0) & ビタミン D & 0 & - \\
\hline
\end{tabular}

表 4 年令構成層別, 食品群・栄養素別の捸取量分布

\begin{tabular}{|c|c|c|c|c|c|}
\hline $\begin{array}{l}\text { 年令構成層 } \\
\text { 食品群 }\end{array}$ & 青年 & 成人 & $\begin{array}{l}\text { 年令構成層 } \\
\text { 栄養素 }\end{array}$ & 青年 & 成人 \\
\hline 穀類 & () & O & エネルギー & 0 & 0 \\
\hline いも類 & O & 0 & 水分 & - & - \\
\hline 砂糖類 & () & (2) & たん白質 & 0 & 0 \\
\hline 菓子類 & O & 0 & 脂肪 & 0 & 0 \\
\hline 油脂類 & 0 & $\bigcirc$ & 糖質 & - & - \\
\hline 種実類 & O & O & 繊維 & - & (0) \\
\hline 豆類 & - & - & 兏分 & - & - \\
\hline 魚介類 & (2) & 0 & カルシウム & (2) & 0 \\
\hline 肉類 & 0 & (2) & ナトリウム & - & - \\
\hline 卵類 & (0) & 0 & リン & 0 & $\bigcirc$ \\
\hline 乳· 乳製品類 & (?) & (2) & 鉄 & (2) & 0 \\
\hline 有色野菜類 & 0 & O & ビタミンA & - & - \\
\hline その他の野菜類 & (0) & (0) & ビタミン $\mathrm{B}_{1}$ & - & - \\
\hline 果実類 & (0) & 0 & ビタミン $\mathrm{B}_{2}$ & (0) & (0) \\
\hline きのこ類 & (0) & - & ニコチン酸 & - & - \\
\hline 海草類 & - & - & ビタミンC & (2) & (0) \\
\hline 嗜好飲料 & (2) & - & ビタミン D & - & - \\
\hline
\end{tabular}


$ら^{6,12)}$ ，性別・年令別という要因を考慮して検討して みた。その結果，この集団は男女ともに砂糖類，種 実類, 肉類, 乳・乳製品類, きのこ類, 海草類およ び嗜好领料は, POISSON 分布近似を示めし,これらの 食品群については性差もなく，同じ摂取状況であっ た。しかし，菓子類，魚介類およびその他の野菜類 のように，男性は BINOMIAL，女性は POLYA 分布近 似を示したものもあり，この分布型から推察すると， 男性は何でもまんべんなく食べ，女性は片寄りのあ る捸取をしているものと考えられた。この逆の食形 態がみられるのは, 油脂類, 豆類および有色野菜類 であり，これら分布型から推察すると食形態は栄養 素摄取量の分布型にも大きく影響を与えると考えら れる。栄養素別にみた分布型では男女ともに, POLYA 分布近似を示めすエネルギー，カルシウム，リン, ビタミン $\mathrm{B}_{1}$ およびビタミン $\mathrm{B}_{2}$, Polsson 分布近似 を示めす灰分では同じ分布近似を示めしていること から，同じ摄取状態を意味していると考える。

年令構成別にみると, 青年層は PoISSON 分布近 似, 成人層は BINOMIAL 分布近似を示す食品群が多 いなかで, 成人で POLYA 分布近似の食品群は魚介類 であり, 青年で POLYA 分布近似を示めすのは肉類で あることから，年秢の違いにより動物性たん白質食 品の選拓のしかたに差のあることが考えられた。

また，栄養素別に観察すると，エネルギー，たん 白質および脂肪はPOLYA 分布近似を示し, 調查集団 においては，これら 3 栄養素の捸取に年令構成別に， かたよりがあるものと推察された。

従来から，種々の調查結果の報告には，それらの 代表值として単なる平均値が示されている。今回わ れわれが行った調査結果に挹いては，攝取量の度数 分布が, 正規型を示した食品群はなく、多くは POLYA 又は, PoISSON 分布近似又は適合であった。 これらの分布においては, 平均値, 最頻値あるいは 中史值は一致しないことがわかっている。したがっ て, 従来の調査にみられるような，平均值だけを对 象群の評価・説明のための代表值として用いること は妥当ではなく，デー夕が正規分布型を示さない場 合は少くとも平均値, 最頻值および中央值を併記し て報告すべきであると考えられる。このように，分 布が正規型（近似を含めて）でない場合は，平均値 のデータの代表値としての意義は制限されなければ ならない。正しくは, データ処理の過程には, 分布 型の検討を組み込んでおくことが必須であり，分布 型を知り調查事項それぞれにおける対象集団の全体
像をとらえた上で，用いるべき代表值を決定すべき であろう。

われわれが行った, 今回の食品群および栄養捸取 量の分布型の検討は, 調查集団の食物捸取の実態を 正しく把握するのに役立つことを明らかにするとと もに, 調査データの分布型検討の必要性を意義づけ たものと考える。

\section{文献}

1 ）赤羽正之, 小野房子, 川端晶子, 五島孜郎, 西 郷光彦：食形態に関する研究。栄養雑誌, 35 ( 1 )，45-53，1977.

2 ) 金光正次，岡田博，甲野礼作，重松冕造，平山 雄：疫学々その応用. 南山堂, 東京, 1965 .

3 ）厚生省公衆衛生局：昭和51年度国民栄盖調査に ついて。栄養日本, 13-25, 1976.

4 ）鈴木継美：食物拱取パターンの研究方法につい て. 日本公衛誌，11（6)，512-529，1964.

5 ) 菅原明子：日本公衛誌，24（5)，313-324, 1977.

6 ）豊川裕之・清水方平：地域集団の食品喍好の分 析について。 日本公衛誌，17（12），999，1970.

7 ）豊川裕之：食物消費を決定する因子, 集団凝集 力, 親和性指数。食品衛生研究, 27 (5), 103 $-112,1972$

8 ）豊川裕之：計量的食生態学. からだの科学, 51 , 32-48, 1973.

9 ) 豊川裕之: 栄盖指導の Stategyの決め方 (4). 臨床栄盖, 45 (1)，39-44, 1974.

10）豊川裕之，三宅由子，伊藤雅治：わが国の食物 攝取に関する研究 (第 1 報)。日本公衛誌,

22 (10), 571-578, 1975.

11）豊川裕之：日本人の食生活を決定している因子。 臨床栄養, $51 （ 6) ， 669-678,1977$.

12）丸井英二：食生活の類似性を測るために。公衆 衛生, 43 ( 5 ), 352-355, 1979.

13）三宅由子, 豊川裕之, 伊藤雅治：わが国の食物 摂取に関する研究 (第 2 報)。日本公衛誌, 23 (11)，689-698， 1976.

14）三宅由子, 丸井英二, 豊川裕之：栄養調査の世 帯別分布とその利用 (第2 報). 日本公衛誌, 24 (10)，特別附録, 370, 1977.

15）三宅由子, 丸井英二, 豊川裕之：栄養調查結果 を被調查世带へ返寸方法。臨床栄養, 52（5）, 452-459, 1978. 
16）平山雄：ガンの疫学. 厚生の指標, $10(4), 13$ $-31,1963$.

\section{要約}

女子栄養短期大学学生々专の家族を对象々した栄 養調查资料をもとに、食品群別・栄盖素摄取量別の 度数分布型による検討を試みた結果、

1. 食品群摂取量の分布型として、POLYA 分布又は 近似を示した食品群は殻類, いも類, 砂糖類, 菓 子類, 種実類, 魚介類, 卵類, 乳 - 乳製品類, そ つ他の野菜類,きのこ類, 海草類および嗜好飲料 デあり, BINOMIAL 分布近似を示したのは, 油脂類 护よび肉類, さらに, PoIsSON 分布近似食品群は豆 類，有色野菜類扩よで果実類であった。また， NORMAL 分布は観察されなか一た。

2. 全国調查（1971：豊川）と同様な分布を示した 食品群はいも類, 菓子類, 豆類, 乳・乳製品類,

有色野菜類, 果実類および海草類であった。この 中で，いも類は POLYA 分布に適合し，かつ, 全国 調査とも一致した。

3. 性別では, 男女ともにPoISSON 分布近似を示し た食品群は砂糖類, 種実類, 肉類, 乳・乳製品類, きのこ類，海草類および嗜好领料であ一た。

4. 主食である殻類では, 男：PoISSON 分布近似, 女：BINOMIAL 分布近似を示したが，いも類では
男：BINOMIAL 分布近似, 女：PoISSON 分布近似 を示した。

油脂類, 豆類および有色野菜は, 男：POLYA 分布 近似を,女：BINOMIAL 分布近似を示し, 性差がみ られた。

5. 栄養素別性別分布型では男・女ともにエネルギ 一, カルシウム, リン, ビタミン $\mathrm{B}_{1}$ およびビタミ ン B $_{2}$ は POLYA 分布近似を, 灰分では POISSON 分 布近似と同じ分布近似を示した。

6 . 年齢層別にみると, 青年層では PoIsSON 分布近 似, 成人層では BINOMIAL 分布近似を示す食品群 が多かった。また, 魚介類では, 成人層が POLYA 分布近似, 青年層が PoISSON 分布近似を示した が，肉類ではこの逆であった。

7. 集団を観察する場合，その集団に関するデー夕 が正規分布をしていない場合は, 求めた平均値は, 必ずしも情報や特性を要約したものとは限らず、 代表值としての意義は制限される。集団について の測定値の分布型は, その集団についての全体像 の理解と平均值などの代表值の選定に役立つ。こ れら統計学的考え方に立って, 食品群および栄養 素捸取量別の分布型を検討したところ，それらの 分布型により, 对象集団の食形態を推察すること ができ，分布型検討の意義を見いだすことができ た。 